\title{
KEJADIAN MIOKARDITIS PASCA PEMBERIAN VAKSIN COVID-19 BERBASIS mRNA
}

\author{
Ronald T. H. Tambunan \\ Dosen Ilmu Penyakit Tropis dan Infeksi, Universitas Methodist Indonesia, Medan, Indonesia \\ Email: docrocixking@gmail.com
}

DOI: https://doi.org/10.46880/methoda.Vol11No3.pp176-184

\begin{abstract}
COVID-19 is still being a pandemic with high morbidity and mortality rate. In Indonesia, there were about 4 million cases with 150 thousand of them ended up in death. The approved COVID-19 vaccines have been successfully in decreasing its morbidity and mortality rate, with $m R N A$-based vaccines such as BNT162b2 and mRNA-1273 have high efficacy. There are reports about post-vaccination adverse event such as myocarditis, therefore a literature review was written about the problem. This article was made as a literature review, collecting previous research articles about myocarditis induced by mRNA COVID-19 vaccine. Data collecting was done subjectively, without using any structured planning systematic and narratively presented. There are seven research articles investigating about post-vaccination myocarditis, which 5 of them concluded about an increasing risk of myocarditis event due to $m R N A$ vaccine, one article stated that $m R N A$ vaccine whether it is BNT162b2 or mRNA-1273, is safe to be used, and one article stated there is no correlation between myocarditis and $m R N A$ vaccination due to a very small incident rate. $m R N A$ COVID-19 vaccines are safe to be used due to their high efficacy in preventing severe clinical manifestations of SARS-CoV-2 infection. Post-vaccination adverse event like myocarditis is very rare and has temporary and mild clinical manifestation in nature.
\end{abstract}

Keyword: COVID-19, SARS-CoV-2, Vaccine, mRNA, Myocarditis.

\begin{abstract}
ABSTRAK
COVID-19 masih menjadi pandemi di seluruh dunia dengan morbiditas dan mortalits yang tinggi. Di Indonesia, tercatat lebih dari 4 juta kasus yang terjadi dan sekitar 150 ribu kematian yang diakibatkannya. Vaksin-vaksin yang beredar sekarang terbukti berhasil dalam menekan angka morbiditas dan mortalitas dari COVID-19, dengan vaksin berbasis metode mRNA seperti BNT162b2 dan mRNA-1273, mempunyai efikasi yang paling tinggi. Akan tetapi terdapat laporan mengenai kejadian miokarditis pasca vaksinasi COVID-19 berbasis metode mRNA. Oleh karena itu dilakukan tinjauan pustaka mengenai kejadian miokarditis pasca pemberian vaksin COVID-19 berbasis mRNA. Metode yang digunakan adalah tinjauan pustaka yaitu mengintegrasikan berbagai penelitian yang sudah pernah dilakukan sebelumnya yang dipilih secara subyektif, tanpa memakai sistematika perencanaan terstruktur, dan disajikan secara naratif. Dari hasil penelusuran, didapatkan tujuh artikel penelitian mengenai miokarditis pasca vaksinasi COVID-19 berbasis mRNA, lima di antaranya menyatakan adanya peningkatan risiko insiden miokarditis pasca vaksinasi, satu artikel menyatakan bahwa vaksin COVID-19 berbasis mRNA aman dan mempunyai efikasi yang tinggi, dan satu artikel menyatakan bahwa tidak ada hubungan antara miokarditis dengan pemberian vaksin. Vaksin COVID-19 berbasis mRNA aman untuk digunakan dan mempunyai efikasi yang tinggi dalam mencegah manifestasi klinis
\end{abstract}

176 | MAJALAH ILMIAH METHODA Volume 11, Nomor 3, September-Desember 2021: 176-184 ISSN: 2088-9534 (media cetak) - ISSN: 2656-6931 (media online) 
berat dari infeksi SARS-CoV-2. Reaksi yang timbul pasca vaksinasi sifatnya sementara dan ringan serta risiko munculnya kejadian miokarditis sangat kecil.

Kata Kunci: COVID-19, SARS-CoV-2, Vaksin, mRNA, Miokarditis.

\section{PENDAHULUAN}

Penyakit Virus Corona 2019/Coronavirus disease 2019 (COVID-19) sejak dilaporkan pada bulan akhir Desember 2019 telah menjadi pandemi di seluruh dunia. Penyakit yang disebabkan Virus Corona penyebab sindroma pernapasan akut berat-2/severe acute respiratory syndrome Corona Virus-2 (SARS-CoV-2) ini tercatat oleh World Health Organisation (WHO) mempunyai morbiditas dan mortalitas yang tinggi, yaitu sekitar 270.000.000 kasus dan sekitar 5.400.000 kematian. Di Indonesia, sejak kasus pertama ditemukan pada bulan Maret 2020, telah terjadi sekitar 4.300 .000 kasus dengan jumlah kematian yang mencapai sekitar 150.000 orang (WHO, 2021b).

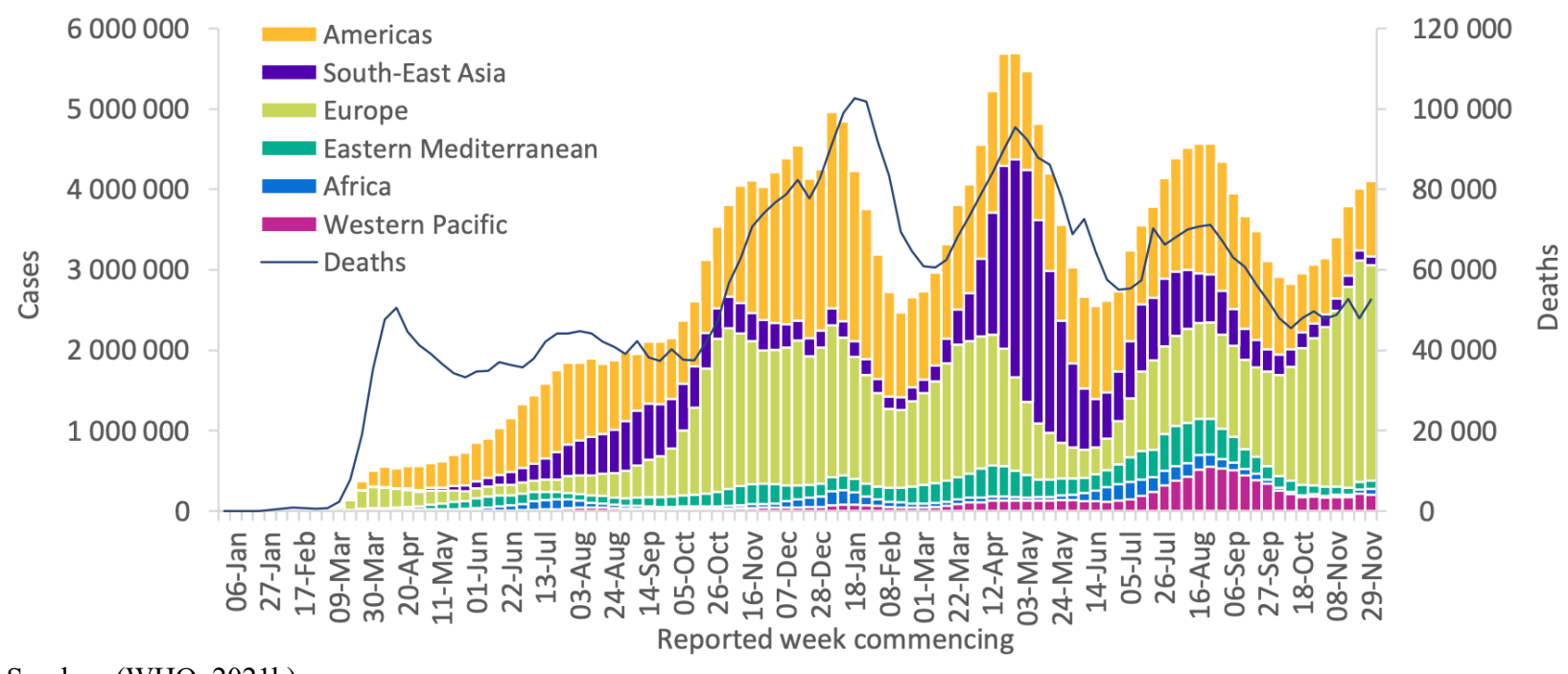

Sumber: (WHO, 2021b)

Gambar 1. Grafik laporan kasus dan kematian yang disebabkan COVID-19 setiap minggu dari berbagai wilayah kerja WHO per tanggal 5 Desember 2021

Untuk mengatasi hal tersebut, para ahli telah berusaha untuk membuat vaksin guna menekan angka kesakitan dan kematian yang diakibatkan oleh infeksi SARS-CoV-2. Berbagai macam vaksin saat ini terbukti dapat menekan angka kejadian kasus baru COVID-19, dari sekitar 900.000 laporan pada bulan April 2021 menjadi sekitar 400.000 kasus pada Desember 2021, di seluruh dunia. Di Indonesia, angka kesakitan akibat infeksi SARS-CoV-2 juga mengalami penurunan dari sekitar 44.000 kasus baru pada Juli 2021 menjadi 160 kasus pada Desember 2021 (Center for Systems Science and Engineering, 2021).

Sejak Edward Jenner menciptakan vaksin pertama pada tahun 1796 (Riedel, 2005), berbagai macam metode pembuatan vaksin telah dikembangkan seperti vaksin dari kuman yang sudah mati, kuman yang sudah dilemahkan (attenuated live), vaksin berdasarkan sub-unit virus, vaksin deoxyribonucleic acid (DNA), dan vaksin messenger ribonucleic acid (mRNA) (Hunt, 2021) Metode vaksin dengan mRNA adalah salah satu dari metode baru pembuatan vaksin, Prinsip dasar dari vaksin ini adalah rangkaian mRNA yang dikelilingi lipid nanoparticle yang menyusun antigen diinjeksikan ke dalam vaksin. Lapisan lipid melindungi mRNA dari aktivitas enzim ribonuklease dan memfasilitasinya untuk dapat masuk ke dalam sel. Kemudian, mRNA kemudian ditranslasikan menjadi protein, diproses dan dipresentasikan kepada sistem imun dengan cara yang biasa. Protein tersebut akan berikatan dengan reseptor sel dan antibodi yang akan menginhibisi ikatan virus dan reseptor 
sel, sehingga mencegah infeksi. Fenomena ini disebut juga sebagai antibodi penetralisir (neutralizing antibodies). Pada kasus infeksi SARS-CoV-2, antigen $\mathrm{S}$ berikatan dengan reseptor angiotensin converting enzyme 2 (ACE2) (Hunt, 2021).

Penelitian sebelumnya mengenai efektivitas vaksin COVID-19 yang berbasis metode mRNA seperti tozinameran BNT162b2 dan mRNA1273, ini memberikan hasil yang baik yaitu di atas 90\% (Shapiro et al., 2021). Akan tetapi, pada bulan Mei 2021, Centers for Disease Control and Prevention (CDC) mengeluarkan pernyataan mengenai adanya kemungkinan hubungan antara vaksin COVID-19 BNT162b2 dan mRNA-1273 dengan miokarditis (Centers for Disease Control and Prevention, 2021). Pada bulan Juni 2021, Kementerian Kesehatan Israel melaporkan 148 kasus miokarditis yang terjadi antara Desember 2020 sampai Mei 2021, yaitu periode program pemberian vaksin di negara tersebut (Israeli Ministry of Health, 2021). Setelah itu, para peneliti di Israel juga melaporkan adanya peningkatan risiko terjadinya miokarditis pada 42 hari pasca vaksinasi sebesar 3,24 (interval keyakinan [IK] 95\%, 1,55-12,44), dibandingkan dengan kelompok individu yang belum divaksin, terutama pada kelompok individu berjenis kelamin laki-laki usia dewasa muda (Barda et al., 2021).

Berdasarkan latar belakang di atas, maka perlu dilakukan sebuah tinjauan pustaka (literature review) mengenai penelitianpenelitian yang mencari hubungan antara vaksin COVID-19 berbasis metode mRNA dengan risiko terjadinya miokarditis. Hal ini perlu untuk dilakukan, mengingat bahwa COVID-19 masih menjadi pandemi di seluruh dunia dan saat ini dengan kemunculan varian baru yaitu omicron (WHO, 2021a), penting untuk dilakukan peninjauan mengenai keuntungan dibandingkan dengan kerugian penggunaan vaksin COVID-19 berbasis metode mRNA.

\section{METODOLOGI}

Artikel ini dibuat berdasarkan metode penyusunan tinjauan pustaka (literature review atau review article) yaitu dengan menggabungkan beberapa hasil penelitian yang sudah pernah dilakukan sebelumnya (integrative literature). Sifat dari tinjauan pustaka adalah naratif dan tidak dibuat secara sistematis, serta pemilihan hasil-hasil penelitian yang akan digabungkan dan dibahas dalam artikel ini berdasarkan subjektifitas penulis, berbeda dengan tinjauan sistematis (systematic review) dan analisis meta yang membutuhkan acuan perencanaan terstruktur dalam pemilihan artikel dan penggunaan analisis statistika secara formal (preferred reporting items for systematic reviews and meta-analysis/PRISMA) (Sastroasmoro, 2014).

Kriteria pemilihan artikel yang ditetapkan dalam tinjauan ini adalah penelitian-penelitian tentang kenaikan insidensi miokarditis pasca pemberian vaksin COVID-19 yang berbasis metode mRNA. Penulis melakukan penelusuran artikel secara daring melalui mesin pencari peramban Google dan tidak melakukan penilaian kualitas artikel-artikel dan tidak melakukan penapisan berdasarkan apakah artikel-artikel yang dipilihnya sudah menjalani proses peer review.

Artikel-artikel yang dipilih adalah artikel penelitian yang menyimpulkan bahwa terdapat dan/atau tidak terdapatnya hubungan antara kejadian miokarditis dengan pemberian vaksin COVID-19 berbasis metode mRNA yaitu vaksin BNT162b2 dan mRNA-1273. Kemudian, artikel-artikel tersebut akan dikompilasi berdasarkan nama peneliti, judul penelitian, dan kesimpulan dari penelitian ke dalam tabel untuk kemudian dilakukan pembahasan mengapa terdapat perbedaan hasil dari penelitianpenelitian tersebut.

\section{HASIL}

Berdasarkan metode penulusuran yang penulis pilih dan lakukan, maka didapatkan tujuh artikel mengenai kejadian miokarditis pasca pemberian vaksin mRNA, seperti yang ditunjukkan pada tabel 1 . 
Tabel 1. Kompilasi artikel penelitian mengenai miokarditis pasca pemberian vaksin COVID-19 mRNA berdasarkan hasil penelusuran

\begin{tabular}{|c|c|c|}
\hline Peneliti & Judul penelitian & Kesimpulan \\
\hline (Baden et al., 2021) & $\begin{array}{l}\text { Efficacy and Safety of the mRNA- } \\
1273 \text { SARS-CoV-2 Vaccine }\end{array}$ & $\begin{array}{l}\text { Tidak perlu adanya kekuatiran akan } \\
\text { keamanan vaksin, walaupun didapati } \\
\text { adanya reaksi lokal dan sistemik yang } \\
\text { sifatnya sementara }\end{array}$ \\
\hline $\begin{array}{l}\text { (Simone et al., } \\
\text { 2021) }\end{array}$ & $\begin{array}{l}\text { Acute Myocarditis Following COVID- } \\
19 \text { mRNA Vaccination in Adults Aged } \\
18 \text { Years or Older }\end{array}$ & $\begin{array}{l}\text { Tidak ditemukan adanya hubungan } \\
\text { antara pemberian vaksin mRNA } \\
\text { COVID-19 dengan miokarditis pasca } \\
\text { vaksinasi }\end{array}$ \\
\hline $\begin{array}{l}\text { (Witberg et al., } \\
\text { 2021) }\end{array}$ & $\begin{array}{l}\text { Myocarditis after COVID-19 } \\
\text { Vaccination in a Large Health Care } \\
\text { Organization }\end{array}$ & $\begin{array}{l}\text { - Didapatkan insiden miokarditis 2,13 } \\
\text { kasus per } 100.000 \text { individu pasca } \\
\text { pemberian vaksin mRNA BNT162b2 } \\
\text { - } \text { Insiden tertinggi pada kelompok usia } \\
\text { 16-29 tahun } \\
\text { - } \text { Miokarditis yang terjadi berada pada } \\
\text { kategori ringan sampai dengan } \\
\text { sedang }\end{array}$ \\
\hline $\begin{array}{l}\text { (Mevorach et al., } \\
\text { 2021) }\end{array}$ & $\begin{array}{l}\text { Myocarditis after BNT162b2 mRNA } \\
\text { Vaccine against COVID-19 in Israel }\end{array}$ & $\begin{array}{l}\text { - Didapatkan insiden miokarditis } \\
\text { pasca vaksinasi BNT162b2, terutama } \\
\text { pada kelompok laki-laki usia dewasa } \\
\text { muda yang telah mendapatkan dosis } \\
\text { kedua } \\
\text { - Gejala miokarditis yang ditemukan } \\
\text { ringan }\end{array}$ \\
\hline (Gundry, 2021) & $\begin{array}{l}\text { Abstract 10712: Observational } \\
\text { Findings of PULS Cardiac Test } \\
\text { Findings for Inflammatory Markers in } \\
\text { Patients Receiving mRNA Vaccines }\end{array}$ & $\begin{array}{l}\text { Vaksin mRNA meningkatkan secara } \\
\text { numerik penanda IL-6, Fas, dan HGF, } \\
\text { sebagai indikator adanya inflamasi } \\
\text { pada endotel dan infiltrat sel T pada } \\
\text { otot-otot kardiak }\end{array}$ \\
\hline $\begin{array}{l}\text { (Montgomery et al., } \\
\text { 2021) }\end{array}$ & $\begin{array}{l}\text { Myocarditis Following Immnunization } \\
\text { With mRNA COVID-19 Vaccines in } \\
\text { Members of the US Military }\end{array}$ & $\begin{array}{l}\text { Didapatkan insiden miokarditis pada } \\
\text { personel militer yang sehat dengan } \\
\text { gejala klinis yang sama pasca } \\
\text { pemberian vaksin mRNA COVID-19. }\end{array}$ \\
\hline (Barda et al., 2021) & $\begin{array}{l}\text { Safety of the BNT162b2 mRNA } \\
\text { COVID-19 Vaccine in a Nationwide } \\
\text { Setting }\end{array}$ & $\begin{array}{l}\text { Ditemukan adanya peningkatan risiko } \\
\text { antara pemberian vaksin BNT162b2 } \\
\text { dengan kejadian miokarditis }\end{array}$ \\
\hline
\end{tabular}

\section{DISKUSI}

Penelitian yang yang menyimpulkan adanya insidensi miokarditis pasca pemberian vaksin COVID-19 berbasis metode mRNA

Penelitian oleh Barda dkk menyimpulkan adanya hubungan antara pemberian vaksin BNT162b2 dengan peningkatan risiko dari kejadian miokarditis. Desain penelitian yang digunakan adalah observasional, membandingkan antara kelompok responden yang divaksin dengan yang belum divaksin berdasarkan sosiodemografik dan variabel klinis. Rasio risiko (RR) dan diferensiasi risiko diukur 42 hari pasca vaksinasi dengan estimator 
Kaplan-Meier. Responden dalam penelitian ini berjumlah 884.828 orang, menghasilkan temuan adanya peningkatan kejadian miokarditis yaitu 1-5 kasus per 100.000 orang (RR 3,24; IK 95\%; 1,0-4,6) (Barda et al., 2021).

Pada penelitian yang dilakukan oleh (Witberg et al., 2021) disimpulkan bahwa didapatkan insiden miokarditis sebesar 2,13 kasus per 100.000 individu pasca pemberian vaksin BNT162b2, dengan insiden tertinggi pada pasien berjenis kelamin laki-laki di kelompok usia 16-29 tahun. Kesimpulan ini didapatkan dari penelitian yang dilakukan di Clalit Health Services di Israel dari 20 Desember 2020 sampai 24 Mei 2021. Periode tersebut dipilih sesuai dengan periode vaksinasi di negara tersebut. Desain penelitian yang digunakan adalah kohort retrospektif, yang berarti dilakukan identifikasi faktor risiko dalam hal ini pemberian vaksin lalu diikuti dalam periode 42 hari untuk kemudian dilihat apakah timbul efek yaitu miokarditis (Sastroasmoro, 2014). Populasi pada penelitian ini sebesar 4.700.000 pasien, dengan kriteria inklusi pemilihan sampel adalah individu berusia 16 tahun ke atas, yang tidak memiliki riwayat miokarditis (dari catatan medis) yang tercatat mendapatkan vaksin dosis pertama 42 hari sebelumnya. Angka 42 ditetapkan oleh karena jarak vaksin dosis pertama dan kedua adalah 21 hari. Pada terdapat pasien-pasien yang meninggal oleh penyebab yang tidak berhubungan dengan COVID-19, tidak lagi terdaftar menjadi pasien, atau belum sampai ke hari 42 di tanggal 24 Mei 2021, maka data pasien akan disensor. Berdasarkan hal tersebut, didapatkan jumlah sampel 2.558.421, dengan 2.401.605 di antaranya (94\%) sudah mendapatkan dosis kedua. Diagnosis miokarditis ditegakkan sesuai dengan tuntunan CDC dan klasifikasi berat atau ringannya penyakit disesuaikan dengan kriteria dari American Heart Associatons (AHA). Analisis Kaplan-Meier digunakan untuk melakukan estimasi insidensi miokarditis yang kemudian distratifikasi berdasarkan jenis kelamin dan usia (Witberg et al., 2021). Analisis Kaplan-Meier adalah salah satu teknik analisis kesintasan yang berprinsip pada pengambilan data sepanjang periode kehidupan (Sastroasmoro, 2014).
Didapatkan 54 individu yang yang memenuhi kriteria diagnosis miokarditis pada penelitian tersebut, yang secara rinci terdiri dari 41 individu mengalami miokarditis ringan, 12 individu mengalami miokarditis sedang, dan 1 mengalami miokarditis fulminan (2,13 kasus; IK $95 \% ; 1,56-2,70)$. Berdasarkan jenis kelamin, insiden tertinggi adalah pasien dengan laki-laki $(10,69$ per 100.000 ; IK 95\%; 6,93-14,46) dan berdasarkan usia paling tinggi berada pada kelompok usia 16-29 tahun. Kelemahan penelitian Witberg dkk yang pertama adalah teknik diagnosis definitif miokarditis yang digunakan adalah biopsi endomiokardial pada satu orang pasien. Kelemahan kedua adalah terdapatnya pengabaian kasus-kasus bila diagnosis miokarditis dilakukan di rumah sakit lain dan adanya keterlambatan dalam pencatatan medis. Didapati juga catatan medis pasien yang kurang lengkap, sehingga berpotensi terjadinuya underestimate pada hasil penelitian tersebut. Selain itu, ketiadaan kelompok pembanding pada penelitian Witberg dkk membuat tidak adanya inferensi untuk memperkuat bukti-bukti penelitian. Terakhir, penelitian tersebut juga tidak memasukkan data-data insiden miokarditis pasca infeksi COVID-19 (Witberg et al., 2021).

Penelitian yang dilakukan oleh (Mevorach et al., 2021) menyimpulkan adanya sedikit peningkatan insidensi miokarditis pasca pemberian vaksin BNT162b2 terutama setelah dosis kedua dengan derajat miokarditis yang ringan. Desain penelitian yang digunakan adalah observasional retrospektif dengan jumlah sampel keseluruhan 9.289.765 orang, dengan analisis Jeffreys-Perks untuk mengukur diferensiasi risiko dan rasio insiden diukur dengan perkiraan Wilson-Hilferty. Hasil penelitian Mevorach dkk menunjukkan 304 orang mengalami simptom miokarditis, 21 orang dinyatakan bukan miokarditis. Dari 283 yang tersisa, 142 orang menunjukkan tanda miokarditis pasca vaksin BNT162b2, dengan rincian 136 orang didiagnosis miokarditsi definitif atau probable. Diferensiasi risiko terjadinya miokarditis antara dosis pertama dan kedua adalah 1,76 per 100.000 orang (IK 95\%; 1,33-2,19), dengan diferensiasi terbesar pada kelompok jenis kelamin laki-laki berusia 16 dan 
19 tahun yaitu sebesar 13,73 per 100.000 orang (IK 95\%; 8,11-19,46). Bila dibandingkan dengan insiden yang diharapkan berdasarkan data sebelumnya, standar rasio insiden adalah 5,34 (IK 95\%; 4,48-6,40) dengan insiden tertinggi pada orang-orang yang menerima dosis kedua yang berjenis kelamin laki-laki kelompok usia 16 dan 19 tahun yaitu 13,60 (IK 95\%; 9,3019,20). Rasio insiden miokarditis 30 hari pasca vaksinasi dosis kedua dibandingkan dengan orang yang belum divaksin adalah 2,35 (IK95\%; 1,10-5,02) dengan insiden tertinggi pada lakilaki usia 16 dan 19 tahun yaitu 8,96 (IK 95\%; $4,50-17,83)$.

Laporan dari (Gundry, 2021) menyimpulkan bahwa pemberian vaksin mRNA meningkatkan proses inflamasi pada endotel dan infiltrasi sel T pada miokard serta meningkatkan risiko terjadinya acute coronary syndrome (ACS), setelah observasi menunjukkan adanya peningkatan trombosis, kardiomiopati, dan masalah vaskular lainnya. Sampel yang digunakan adalah 566 pasien yang diuji dengan metode Protein Unstable Lesion Signature (PULS) yang mengukur kadar protein-protein yang dianggap sebagai biomarker sebagai respon imun adanya lesi pada arteri. Uji ini juga dapat memprediksi risiko terjadinya ACS dalam 5 tahun ke depan. Biomarker yang diukur adalah interleukin 16 (IL-16), soluble Fas, dan Hepatocyte Growth Factor (HGF). Uji ini dilakukan setiap 3-6 bulan selama 8 tahun. Pada pandemi COVID-19 dan pemberian vaksin COVID-19 mRNA, dilakukan pemeriksaan 210 minggu pasca dosis kedua vaksin, dengan rasio laki-laki dan perempuan yaitu $1: 1$, berusia 28-97 tahun. Hasil dari uji PULS mengalami peningkatan secara drastis yaitu nilai IL-16 meningkat dari 35 $=/-20$ menjadi $82=/-75$; sFas meningkat dari $22+/-15$ menjadi $46=/-24$; HGF meningkat dari 42+/-12 menjadi 86+/-31 Perubahan ini meningkatkan risiko ACS dari $11 \%$ dalam 5 tahun menjadi $25 \%$ dalam 5 tahun. Peningkatan biomarker ini bertahan selama kurang lebih 2,5 bulan. Kelemahan dari penelitian ini adalah belum dilakukannya uji analitik untuk melihat kekuatan hubungan antara pemberian vaksin dengan insiden miokarditis dan belum dijelaskan apakah jumlah sampel sudah dapat dianggap mewakili jumlah individu yang menerima vaksin COVID-19 mRNA secara nasional, serta kesimpulan ditarik berdasarkan uji PULS pada pasien-pasien di tempat penelitian tersebut, bukan berdasarkan hasil biopsi miokard.

Penelitian (Montgomery et al., 2021) menyimpulkan didapatkan kejadian miokarditis pada anggota militer yang sehat setelah mendapatkan vaksin COVID-19 mRNA. Metode yang digunakan pada penelitian ini adalah tinjauan kasus secara retrospektif dari rumah sakit milter nasional Walter Reed yang melibatkan 23 pasien laki-laki (22 anggota aktif dan 1 pensiunan) dengan nilai median usia 25 (20-51) tahun, dievaluasi antara bulan Januari sampai April 2021, untuk dilihat apakah ada keluhan nyeri dada akut 4 hari pasca vaksinasi COVID-19 mRNA. Tujuh orang mendapatkan vaksin BNT162b2 dan 16 orang mendapatkan mRNA-1273. Dua puluh pasien mengalami simptom pasca dosis kedua, tetapi seluruhnya mengalami peningkatan kadar troponin jantung Delapan orang menjalani pemeriksaan magnetic resonance imaging (MRI) yang hasilnya konsisten dengan diagnosis klinis miokarditis. Kelemahan dari penelitian ini adalah pengunaan surveilans secara pasif, sehingga tidak dapat mengidentifikasi semua kasus. Periode observasi pasca vaksinasi yang singkat, sampel yang dianggap tidak mewakili populasi umum, belum adanya keseragaman dalam evaluasi klinis, dan belum dicantumkannya uji yang dijalani pasien di berbagai rumah sakit.

\section{Penelitian yang menyimpulkan tidak didapati adanya insiden miokarditis pasca pemberian vaksin COVID-19 berbasis metode mRNA}

Penelitian (Baden et al., 2021) menyimpulkan bahwa tidak ada bahaya keamanan dari penggunaan vaksin mRNA-1273 walaupun dijumpai adanya reaksi lokal dan sistemik yang bersifat sementara. Penelitian ini menggunakan uji randomized clinical trial di 99 tempat di Amerika Serikat (AS) antara 27 Juli23 Oktober 2020, melibatkan responden berusia 18 tahun ke atas yang belum pernah terinfeksi SARS-CoV-2 sebelumnya. Total responden 
berjumlah 30.420 orang yang dirandomisasi menjadi dua grup yang sama jumlahnya yaitu 15.210 orang menerima 2 dosis plasebo atau vaksin mRNA-1273. Sebanyak 185 responden di kelompok plasebo mengalami gejala COVID-19 (56,5 per 1000 orang-tahun; IK 95\%; 48,7$65,3)$, sedangkan di kelompok penerima vaksin terdapat 11 responden mengalami simptom (3,3 per 1000 orang-tahun; IK 95\%; 1,7-6,0). Efikasi vaksin sebesar 94,1\% (IK 95\%; 89,3-96,8\%; $\mathrm{P}<0,001$ ), dengan reaktogenisitas yang sedang dan bersifat sementara serta hampir tidak ditemui reaksi yang tidak diinginkan dari pemberian vaksin. Kelemahan dari penelitian ini adalah penilaian mengenai efikasi dan keamanan vaksin dilakukan dalam jangka waktu yang berdeketan.

Penelitian (Simone et al., 2021) menyimpulkan bahwa tidak ditemukannya hubungan antara pemberian vaksin mRNA dengan miokarditis pasca vaksinasi. Penelitian tersebut dilakukan di Kaiser Permanente Southern California (KPSC) dengan responden berjumlah 2.392 .924 berusia 18 tahun ke atas, mendapatkan sedikitnya satu dosis BNT162b2 (50\%) atau mRNA-1273 (50,2\%), dan menggunakan desain penelitian prospektif kohort. Terdapat 15 kasus terkonfirmasi miokarditis oleh sedikitnya 2 dokter spesialis jantung dan pembuluh darah (2 orang setelah dosis Pertama, 13 orang setelah dosis kedua). Insiden miokarditis 0,8 kasus per satu juta dosis Pertama dan 5,8 kasus per satu juta dosis kedua yang diobservasi 10 hari pasca vaksinasi. Responden yang mengalami miokarditis semuanya laki-laki dengan nilai median (IQR) 25 (20-32) tahun. Lima belas pasien tersebut sebelumnya tidak mengalami penyakit jantung, dengan 8 orang mendapatkan vaksin BNT162b2 dan 7 orang mendapatkan vaksin mRNA1273.12 Semuanya kemudian dirawat di rumah sakit dan dari pemeriksaan polymerase chain reaction (PCR) dinyatakan negatif infeksi SARS-CoV-2. Kesimpulan dari penelitian ini ditarik oleh karena sangat rendahnya kasus miokarditis yang terjadi (5,8 kasus per 1.000 .000 orang). Selain itu, kelemahan dari penelitian ini adalah penggunaan desain observasional, waktu follow-up yang singkat, tidak dilakukannya biopsi miokard sebagai diagnosis definitif, tidak adanya keseragaman dalam uji kasus, tidak dilakukan penyelidikan lebih lanjut terhadap potensi penyebab keluhan nyeri dada pasca vaksinasi, potensi tidak terdiagnosisnya kasus asimptomatik, dan perhitungan statistik yang menyatakan tidak adanya hubungan antara pemberian vaksin dengan miokarditis.

Dari hasil penelitian di atas, ditemukan sebanyak tujuh penelitian, lima menyimpulkan terdapat adanya peningkatan risiko kejadian miokarditis pasca vaksinasi dan dua menyimpulkan tidak adanya hubungan antara pemberian vaksin dengan kejadian miokarditis. Hal tersebut seyogyanya mendapatkan perhatian lebih serius mengenai keamanan vaksin COVID19 berbasis metode mRNA. Tetapi, mengingat situasi pandemi COVID-19 yang belum berakhir, maka penggunaan vaksin COVID-19 berbasis metode mRNA tetap bisa dilanjutkan mengingat insiden terjadinya miokarditis pasca vaksinasi sangat jarang $(0,001-0,005 \%$ pada penelitian (Barda et al., 2021), 0,00213\% pada penelitian (Witberg et al., 2021), dan 0,00176\% pada penelitian (Mevorach et al., 2021)). Penelitian yang dilakukan oleh Gundry dkk belum melakukan uji analitik, baru sebatas laporan kasus yang ditemukan di klinik mereka dengan jumlah sampel sedikit, sama dengan penelitian (Montgomery et al., 2021). Sebaliknya, manfaat dari vaksin COVID-19 berbasis mRNA mempunyai manfaat yang besar dalam menekan angka kesakitan dan kematian yang diakibatkan oleh infeksi SARS-CoV-2, seperti yang disimpulkan pada penelitian Baden dkk bahwa vaksin COVID-19 aman untuk digunakan dan mempunyai efikasi sebesar 94\% dengan potensi kecil reaksi lokal dan sistemik yang sifatnya ringan dan sementara serta penelitian Simone dkk yang menggunakan jumlah sampel yang besar menyimpulkan walaupun didapatkan insiden miokarditis, tetapi secara uji statistika mempunyai hasil yang sangat kecil $(0,00008-0,00058 \%$ kejadian $)$ (Baden et al., 2021; Simone et al., 2021).

Kelemahan dari tinjauan pustaka ini adalah sifatnya yang naratif dan tidak dibuat secara sistematis, serta pemilihan hasil-hasil penelitian yang akan digabungkan dan dibahas dalam 
artikel ini berdasarkan subjektifitas penulis, berbeda dengan tinjauan sistematis (systematic review) dan analisis meta yang membutuhkan acuan perencanaan terstruktur dalam pemilihan artikel dan penggunaan analisis statistika secara formal (preferred reporting items for systematic reviews and meta-analysis/PRISMA). Selain itu, penelusuran artikel-artikel ilmiah yang ditampilkan pada tinjauan pustaka ini melalui mesin pencari peramban Google dan tidak melakukan penilaian kualitas artikel-artikel dan tidak melakukan penapisan berdasarkan apakah artikel-artikel yang dipilihnya sudah menjalani proses peer review.

\section{KESIMPULAN}

Dari hasil tinjauan pustaka di atas, disimpulkan bahwa terdapat insiden miokarditis pasca vaksinasi COVID-19 berbasis metode mRNA seperti BNT162b2 dan mRNA-1273, akan tetapi angka kejadiannya dan risikonya sangat kecil bila dibandingkan dengan manfaatnya dalam menekan angka kesakitan dan kematian, serta mencegah manifestasi klinis yang berat yang diakibatkan oleh infeksi SARSCoV-2.

\section{DAFTAR PUSTAKA}

Baden, L. R., El Sahly, H. M., Essink, B., Kotloff, K., Frey, S., Novak, R., ... Zaks, T. (2021). Efficacy and Safety of the mRNA-1273 SARS-CoV-2 Vaccine. New England Journal of Medicine, 384(5), 403-416. https://doi.org/10.1056/NEJMoa2035389

Barda, N., Dagan, N., Ben-Shlomo, Y., Kepten, E., Waxman, J., Ohana, R., ... Balicer, R. D. (2021). Safety of the BNT162b2 mRNA Covid-19 Vaccine in a Nationwide Setting. New England Journal of Medicine, 385(12), 1078-1090. https://doi.org/10.1056/NEJMoa2110475

Center for Systems Science and Engineering. (2021). COVID-19 Dashboard. Retrieved from https://www.arcgis.com/ website: https://www.arcgis.com/

Centers for Disease Control and Prevention. (2021). Myocarditis and pericarditis following mRNA COVID-19 vaccination. Retrieved from https://www.cdc.gov/coronavirus website: https://www.cdc.gov/coronavirus

Gundry, S. R. (2021). Abstract 10712:

Observational Findings of PULS Cardiac

Test Findings for Inflammatory Markers in Patients Receiving mRNA Vaccines.

Circulation, 144(Suppl_1).

Hunt, R. (2021). Vaccines: past successes and future prospects from smallpox to COVID-19. Retrieved from https://www.microbiologybook.org website: https://www.microbiologybook.org/

Israeli Ministry of Health. (2021). Surveillance of myocarditis (inflammation of the heart muscle) cases between December 2020 and May 2021 (including). Retrieved from https://www.gov.il/ website: https://www.gov.il/

Mevorach, D., Anis, E., Cedar, N., Bromberg, M., Haas, E. J., Nadir, E., ... Alroy-Preis, S. (2021). Myocarditis after BNT162b2 mRNA Vaccine against Covid-19 in Israel. New England Journal of Medicine, 385(23), 2140-2149. https://doi.org/10.1056/NEJMoa2109730

Montgomery, J., Ryan, M., Engler, R., Hoffman, D., McClenathan, B., Collins, L., ... Cooper, L. T. (2021). Myocarditis Following Immunization With mRNA COVID-19 Vaccines in Members of the US Military. JAMA Cardiology, 6(10), 1202.

https://doi.org/10.1001/jamacardio.2021.2 833

Riedel, S. (2005). Edward Jenner and the History of Smallpox and Vaccination. Baylor University Medical Center Proceedings, 18(1), 21-25. https://doi.org/10.1080/08998280.2005.11 928028

Sastroasmoro, S. (2014). Dasar-dasar metodologi Penelitian Klinis (Edisi ke-5). Jakarta: Sagung Seto.

Shapiro, J., Dean, N. E., Madewell, Z. J., Yang, Y., Halloran, M. E., \& Longini, I. M. (2021). Efficacy Estimates for Various COVID-19 Vaccines: What we Know from the Literature and Reports. MedRxiv, $1-34$.

https://doi.org/10.1101/2021.05.20.21257 461

Simone, A., Herald, J., Chen, A., Gulati, N., Shen, A. Y.-J., Lewin, B., \& Lee, M.-S. (2021). Acute Myocarditis Following COVID-19 mRNA Vaccination in Adults Aged 18 Years or Older. JAMA Internal 
Medicine, 181(12), 1668.

https://doi.org/10.1001/jamainternmed.20

21.5511

WHO. (2021a). Update on Omicron. Retrieved from https://www.who.int/ website: https://www.who.int/

WHO. (2021b). Weekly epidemiological update on COVID-19. Retrieved from https://www.who.int/ website: https://www.who.int/

Witberg, G., Barda, N., Hoss, S., Richter, I., Wiessman, M., Aviv, Y., ... Kornowski, R. (2021). Myocarditis after Covid-19 Vaccination in a Large Health Care Organization. New England Journal of Medicine, 385(23), 2132-2139. https://doi.org/10.1056/NEJMoa2110737 